\title{
Effect of Fractionated Doses of Cerastes Cerastes Crude Venom on Tissues of Irradiated Mice
}

\author{
O. M. Ashry, S. F. Salama\# and H. F. Hassan
}

Radiation Biology Dept., National Centre for Radiation Research and Technology (NCRRT), P. O. Box; 29 Nasr City, Egypt. ${ }^{\#}$ E.mail;:Salamafaried@Yahoo.com.

\footnotetext{
7 HIS WORK aims to study the effect of fractionated doses of Cerastes cerastes (C. cerastes) crude venom (CCV) on physiological alterations in different tissues of 5.5 Gy $\gamma$ irradiated mice. Male mice were grouped into: Control group. CCV group; mice received via inter peritoneum (i.p.) $1 / 3$ LD50 $\mathrm{CCV}$ in fractionated doses over a period of 2 weeks. Irradiated group; mice whole body exposed to 5.5 Gy $\gamma$-rays. Irradiated+ $\mathrm{CCV}$; mice received via i.p $1 / 3 \mathrm{LD} 50 \mathrm{CCV}$ in fractionated doses over a period of 2 weeks starting $1 \mathrm{~h}$ post irradiation. Exposure to 5.5 Gy $\gamma$-rays elevated advanced oxidation protein products (AOPP) and malondialdehyde (MDA) levels and decreased glutathione $(\mathrm{GSH})$ content of liver, spleen and kidney. Moreover, $\gamma$-irradiation significantly decreased calcium (Ca) and elevated zinc $(\mathrm{Zn})$, and cupper $(\mathrm{Cu})$ in liver, spleen and kidney tissues compared to the control, whereas, iron (Fe) was significantly elevated in liver and spleen and decreased in kidney. In addition, serum urea and creatinine and their ratio were significantly increased. Irradiated mice treated with fractionated CCV showed significant amelioration of oxidative stress and element alterations in the different tissues. It could be concluded that the fractionated doses of CCV ( $1 / 3$ LD50) might have favourable potential against irradiation inducedbiochemical injuries.

Keywords: Cerastes crude venom, Oxidative stress, Trace Elements, $\gamma$-rays.
}

Venoms are excellent sources of molecules for drug discovery, and once purified, characterized, and cloned, could have potential applications in medicine. Snake procoagulant molecules, especially from the Viperidae family, have been used in medical applications and as diagnostic tools (Suntravat et al., 2010). Cerastes is a small genus of vipers found in North Africa and the Middle East (Phelps, 2010). 
Indian Monocellate Cobra venom treatment increased glutathione (GSH) level and thereby it may prevent peroxidation in arthritis. Cobra venom not only modulates inflammatory activity, but it also possesses anti complementary activity (Gomes et al., 2010). A cytotoxic and antioxidant protein (NN-32) from the Indian spectacled cobra Naja naja venom increased the antioxidant markers GSH, glutathione peroxidase, glutathione transferase, superoxide dismutase and catalase activity. NN-32 increased serum IL-10 level (Das et al., 2011). A bradykinin potentiating factor extracted from the Egyptian viper Androctonus amoreuxi venom offered a radio protective effect to irradiated rats (Ashry et al., 2012).

The growing application of radiation science in different settings (e.g., radiotherapy, biomedical research, military and space research) necessitates protecting humans against the harmful effects of radiation. During radiotherapy, ionizing radiation interacts with biological systems to produce free radicals or reactive oxygen species (ROS), which attack various cellular components including DNA, proteins and membrane lipids, leading to serious cellular damage (Shirazi et al., 2013).

The antioxidant enzymes superoxide dismutase, catalase, glutathione peroxidase, glutathione reductase and enzymes of the hexose monophosphate shunt, require cofactors such as trace elements and other relevant ones: selenium (Se), manganese ( $\mathrm{Mn}), \mathrm{Cu}, \mathrm{Zn}$, and also $\mathrm{Mg}$ to maintain their function (Jozanov-Stankov et al., 1998). Deposition of these elements may have some additional role on the toxicity caused by direct radiation of the kidney (Cengiz et al., 2003). A marked increase was noted in serum calcium content with concomitant decrease in the bone calcium which suggests that irradiation of rats resulted in disturbances of calcium metabolism (Edrees et al., 2008).

Our work aims to study the effects of fractionated CCV (1/3LD50) on $\gamma$ rays induced oxidative stress biomarkers, biochemical changes and trace elements in tissues of mice.

\section{Materials and Methods}

\section{Animals}

Twenty four adult male mice, weighing ( $24 \pm 2 \mathrm{~g})$ were obtained from the Nuclear Research Centre (NRC), Anchas, Atomic Energy Authority-Egypt. Egypt. J. Rad. Sci. Applic., Vol. 27, No. 1-2 (2014) 
Animals were allowed to acclimate in metal cages inside a well-ventilated room for 2 weeks prior to the commencement of the experiment. They were maintained under normal conditions, temperature $18-23^{\circ} \mathrm{C}$, fed on standard commercial pellet diet and had free access to tap water.

\section{Venom}

Snakes; $C$. cerastes venom was kindly provided by Dr Ahmad Abd El Baset, $\mathrm{PhD}$, Faculty of Medicine, Ain Shams University, Cairo, Egypt. Snakes were collected from the Western Desert in Upper Egypt. The snakes were kept in large tanks, heat was provided from a 100 watt lamp for a daily period of $9 \mathrm{~h}$. Water was always available. Venom was milked from adult snakes, lyophilized and Venom was dissolved in saline solution $(0.9 \% \mathrm{Na} \mathrm{Cl})$ at a concentration of $1 \mathrm{mg} / \mathrm{ml}$ prior to use.

\section{Radiation facility}

Irradiation was performed at NCRRT, Cairo, Egypt, using a Gamma Cell$40\left({ }^{137}\right.$ Cesium) biological irradiator manufactured by the Atomic Energy of Canada Ltd, Ottawa, Ontario, Canada. Mice were irradiated at a single dose of $5.5 \mathrm{~Gy}$ given at a dose rate of $0.49 \mathrm{~Gy} / \mathrm{min}$.

\section{The study protocol}

Animals matched in age and body size were randomly assigned into four groups; control group; animals were injected i.p. with saline solution only. CCV group; animals injected via i.p. $1 / 3$ LD50 (Al-Sadoon et al., 2013) CCV in a diluted form over a period of 2 weeks. Irradiated group; animals were exposed to $5.5 \mathrm{~Gy}$ of $\gamma$-radiation. Irradiated and CCV; animals were irradiated at $5.5 \mathrm{~Gy}$ and injected i.p., $1 \mathrm{~h}$ post irradiation, with $1 / 3 \mathrm{LD} 50$ of diluted crude CCV daily for 2 weeks. After 2 weeks, mice were anesthetized with ether. Blood was collected by heart puncture, centrifuged and serum was stored at $-20^{\circ} \mathrm{C}$ until analyzed.

The liver, kidney and spleen were dissected out, washed in deionized water. For oxidative stress biomarkers a known wt of the different organs was used to obtain a $10 \%$ tissue homogenate in $0.15 \mathrm{M} \mathrm{KCl}$. Reduced GSH content was measured by spectrophotometry at $412 \mathrm{~nm}$ in blood, based on the determination of yellow colour that develops (Beutler et al., 1963). Lipid Egypt. J. Rad. Sci. Applic., Vol. 27, No. 1-2 (2014) 
peroxidation was based on the determination of MDA which reacts with thiobarbituric acid in acidic medium to yield a pink colour trimethine complex at $532 \mathrm{~nm}$ (Yoshioka et al., 1979). AOPP were measured by spectrophotometry on a microplate reader (990 win6 software for DV990BV4.GIO.DE VITA. Roma, Italy) and were calibrated with chloramine-T solutions that is measured in the presence of potassium iodide at $340 \mathrm{~nm}$ (Witko-Sarsat et al. 1998). AOPP concentrations were expressed as $\mu \mathrm{mol} / \mathrm{L}$ of chloramine- $\mathrm{T}$ equivalents. To determine possible kidney injury by venom utilization, urea and creatinine were determined using Stanbio kits according to the method of Young (2001) and Spierto et al. (1979), respectively.

Liver, spleen and kidney were isolated and tissue samples were digested in pure nitric acid and $\mathrm{H}_{2} \mathrm{O}_{2}$ (4:1) by Microwave Sample Preparation Labstation, MLS-1200 MEGA model, Italy (Kingston and Jassie, 1988). Trace elements $(\mathrm{Cu}, \mathrm{Zn}, \mathrm{Fe}$ and $\mathrm{Ca})$ were estimated using Atomic Absorption Unicam 939 Solar Spectrometer, England.

\section{Statistical analysis}

The results are presented as percentage and mean \pm S.E. Statistical analysis was performed using one-way analysis of variance (ANOVA), statistical package of social science (SPSS) version 15.0 for windows. Individual difference among groups was analysed by Duncan's test. Significance was indicated at $P<0.05$

\section{Results}

Results showed that CCV treated animals revealed no significant differences $(P<0.05)$ compared to control group after 2 weeks for all investigated parameters. Exposure of animals to 5.5 Gy $\gamma$-rays induced oxidative stress demonstrated by a significant $(P<0.05)$ decrease of GSH content associated with significant increase of AOPP and MDA levels in liver tissue compared to the control group (Table 1). Results also revealed that irradiation induced significant elevation of liver $\mathrm{Zn}, \mathrm{Cu}$ and $\mathrm{Fe}$, whereas $\mathrm{Ca}$ was significantly depressed compared to the control group (Table 2). Irradiated group that received CCV showed significant decrease of liver AOPP, MDA, Zn, $\mathrm{Cu}$ and $\mathrm{Fe}$, while $\mathrm{GSH}$ content and $\mathrm{Ca}$ were significantly increased compared to the irradiated group. (Tables1 and 2).

Egypt. J. Rad. Sci. Applic., Vol. 27, No. 1-2 (2014) 
TABLE 1. Effect of CCV on liver AOPP, MDA, and GSH contents (nmol/g tissue) of $5.5 \mathrm{~Gy}$ irradiated mice.

\begin{tabular}{|c|c|c|c|}
\hline Groups & AOPP & MDA & GSH \\
\hline Control & $201.5 \pm 5.3$ & $200.2 \pm 5.9$ & $21.8 \pm 1.3$ \\
\hline CCV & $193.5 \pm 7.2$ & $191.2 \pm 7.2$ & $23.1 \pm 1.5$ \\
\hline Irradiated (5.5Gy) & $233.2 \pm 5.2 \mathrm{a}$ & $262.3 \pm 5.6 \mathrm{a}$ & $16.5 \pm 1.8 \mathrm{a}$ \\
\hline Irradiated+ CCV & $214.8 \pm 3.6 \mathrm{~b}$ & $220.5 \pm 10.8 \mathrm{~b}$ & $19.0 \pm 1.1 \mathrm{~b}$ \\
\hline
\end{tabular}

a: significantly different from control. b: significantly different from irradiated group.

TABLE 2: Effect of CCV on liver Zn, Cu, Ca nd Fe contents ( $\mu \mathrm{g} / \mathrm{g}$ tissue) in $5.5 \mathrm{~Gy}$ irradiated mice.

\begin{tabular}{|c|c|c|c|c|}
\hline Groups & $\mathbf{Z n}$ & $\mathbf{C u}$ & $\mathbf{C a}$ & $\mathbf{F e}$ \\
\hline Control & $29.2 \pm 1.1$ & $3.4 \pm 0.02$ & $69.2 \pm 3.4$ & $83.2 \pm 3.5$ \\
\hline CCV & $28.4 \pm 1.1$ & $3.6 \pm 0.3$ & $70.5 \pm 4.8$ & $78.6 \pm 2.6$ \\
\hline Irradiated (5.5Gy) & $35.2 \pm 1.5 \mathrm{a}$ & $4.5 \pm 0.2 \mathrm{a}$ & $54.1 \pm 2.8 \mathrm{a}$ & $104.5 \pm 4.6 \mathrm{a}$ \\
\hline Irradiated+ CCV & $27.3 \pm 1.6 \mathrm{~b}$ & $3.8 \pm 0.1 \mathrm{~b}$ & $68.9 \pm 4.9 \mathrm{~b}$ & $87.8 \pm 3.1 \mathrm{~b}$ \\
\hline
\end{tabular}

Legends as in Table 1.

Exposure of mice to $5.5 \mathrm{~Gy}$ provoked oxidative stress in the spleen demonstrated by significant $(P<0.05)$ decrease of GSH content and Ca associated with significant elevations of AOPP and MDA in addition to $\mathrm{Zn}, \mathrm{Cu}$ and $\mathrm{Fe}$ levels compared to the control group (Tables 3 and 4). Irradiated group that received CCV showed significant $(P<0.05)$ decrease of spleen AOPP, MDA, as well as $\mathrm{Zn}, \mathrm{Cu}$ and $\mathrm{Fe}$ levels, while GSH content and $\mathrm{Ca}$ level were increased significantly compared to the irradiated group.

TABLE 3. Effect of CCV on spleen AOPP, MDA and GSH contents (nmol/g tissue) of $5.5 \mathrm{~Gy}$ irradiated mice.

\begin{tabular}{|c|c|c|c|}
\hline Groups & AOPP & MDA & GSH \\
\hline Control & $198.8 \pm 5.7$ & $194.8 \pm 5.6$ & $20.0 \pm 1.2$ \\
\hline CCV & $196.3 \pm 6.7$ & $195.9 \pm 8.9$ & $22.9 \pm 0.8$ \\
\hline Irradiated (5.5Gy) & $243.3 \pm 4.4 \mathrm{a}$ & $259.9 \pm 4.5 \mathrm{a}$ & $14.8 \pm 0.7 \mathrm{a}$ \\
\hline Irradiated+ CCV & $218.3 \pm 5.0 \mathrm{ab}$ & $220.9 \pm 6.2 \mathrm{ab}$ & $17.9 \pm 1.0 \mathrm{~b}$ \\
\hline
\end{tabular}

Legends as in Table 1.

TABLE 4. Effect of CCV on spleen $\mathrm{Zn}, \mathrm{Cu}, \mathrm{Ca}$ and Fe contents ( $\mu \mathrm{g} / \mathrm{g}$ tissue) of $5.5 \mathrm{~Gy}$ irradiated mice.

\begin{tabular}{|c|c|c|c|c|}
\hline Groups & $\mathbf{Z n}$ & $\mathbf{C u}$ & $\mathbf{C a}$ & Fe \\
\hline Control & $29.4 \pm 1.5$ & $1.5 \pm 0.1$ & $76.1 \pm 3.7$ & $166.8 \pm 6.7$ \\
\hline CCV & $30.0 \pm 1.3$ & $1.6 \pm 0.2$ & $74.3 \pm 3.7$ & $161.5 \pm 5.3$ \\
\hline Irradiated (5.5Gy) & $35.6 \pm 1.1 \mathrm{a}$ & $2.5 \pm 0.2 \mathrm{a}$ & $61.7 \pm 3.9 \mathrm{a}$ & $210 \pm 9.4 \mathrm{a}$ \\
\hline Irradiated+ CCV & $30.1 \pm 1.0 \mathrm{~b}$ & $1.8 \pm 0.1 \mathrm{~b}$ & $73.3 \pm 3.6 \mathrm{ab}$ & $180.8 \pm 7.4 \mathrm{~b}$ \\
\hline
\end{tabular}

Legends as in Table 1.

Egypt. J. Rad. Sci. Applic., Vol. 27, No. 1-2 (2014) 
Irradiation induced significant increase in AOPP, MDA, $\mathrm{Zn}$ and $\mathrm{Cu}$ accompanied with a significant decline in GSH content, $\mathrm{Ca}$ and $\mathrm{Fe}$ in the kidneys as compared to the control, (Table $5 \& 6$ ). Irradiated group treated with $\mathrm{CCV}$ exhibited significant $(P<0.05)$ decline in AOPP, MDA, $\mathrm{Zn}$ and $\mathrm{Cu}$ whereas kidney GSH content, $\mathrm{Ca}$ and $\mathrm{Fe}$ were elevated significantly compared to the irradiated group.

TABLE 5. Effect of CCV on kidney AOPP, MDA and GSH contents (nmol/g tissue) of 5.5 Gy irradiated mice.

\begin{tabular}{|c|c|c|c|}
\hline Groups & AOPP & MDA & GSH \\
\hline Control & $212.7 \pm 6.3$ & $101.4 \pm 3.4$ & $20.0 \pm 0.9$ \\
\hline CCV & $205.8 \pm 5.4$ & $83.6 \pm 4.5$ & $18.4 \pm 1.2$ \\
\hline Irradiated (5.5Gy) & $243.0 \pm 5.6 \mathrm{a}$ & $124.4 \pm 4.5 \mathrm{a}$ & $14.5 \pm 0.9 \mathrm{a}$ \\
\hline Irradiated+ CCV & $214.8 \pm 5.6 \mathrm{~b}$ & $107.2 \pm 4.5 \mathrm{~b}$ & $18.9 \pm 0.9 \mathrm{~b}$ \\
\hline
\end{tabular}

Legends as in Table 1.

TABLE 6. Effect of CCV on kidney $\mathrm{Zn}, \mathrm{Cu}, \mathrm{Mg}, \mathrm{Ca}$ and Fe contents ( $\mu \mathrm{g} / \mathrm{g}$ tissue) of $5.5 \mathrm{~Gy}$ irradiated animals.

\begin{tabular}{|c|c|c|c|c|}
\hline Groups & $\mathbf{Z n}$ & $\mathbf{C u}$ & $\mathbf{C a}$ & $\mathbf{F e}$ \\
\hline Control & $29.3 \pm 1.8$ & $5.4 \pm 0.1$ & $82.6 \pm 4.1$ & $76.4 \pm 3.2$ \\
\hline CCV & $29.5 \pm 1.5$ & $5.6 \pm 0.3$ & $80.0 \pm 4.7$ & $78.6 \pm 3.6$ \\
\hline Irradiated (5.5Gy) & $35.1 \pm 1.6 \mathrm{a}$ & $6.5 \pm 0.2 \mathrm{a}$ & $63.7 \pm 3.2 \mathrm{a}$ & $69.4 \pm 2.3 \mathrm{a}$ \\
\hline Irradiated+ CCV & $29.9 \pm 1.5 \mathrm{~b}$ & $5.1 \pm 0.3 \mathrm{~b}$ & $77.0 \pm 4.6 \mathrm{~b}$ & $78.5 \pm 2.6 \mathrm{~b}$ \\
\hline
\end{tabular}

Legends as in Table 1.

Also, serum urea, creatinine levels and their ratio showed a significant increase in irradiated animals (Table 7). Treatment of irradiated animals with $\mathrm{CCV}$ induced significant decline of serum urea, creatinine levels and their ratio.

TABLE 7. Effect of CCV on serum creatinine, urea and urea/creatinine ratio of 5.5 Gy irradiated animals.

\begin{tabular}{|c|c|c|c|}
\hline Groups & Creatinine mg/dl & Urea mg/dl & Urea/creatinine \\
\hline Control & $5.1 \pm 0.17$ & $53.5 \pm 2.1$ & $9.4 \pm 0.3$ \\
\hline CCV & $4.4 \pm 0.2$ & $50.6 \pm 2.1$ & $11.9 \pm 0.9$ \\
\hline Irradiated (5.5Gy) & $5.8 \pm 0.32 \mathrm{a}$ & $65.3 \pm 1.7 \mathrm{a}$ & $12.3 \pm 0.3 \mathrm{a}$ \\
\hline Irradiated+ CCV & $4.4 \pm 0.36 \mathrm{ab}$ & $50.5 \pm 1.9 \mathrm{~b}$ & $10.4 \pm 0.6 \mathrm{~b}$ \\
\hline
\end{tabular}

Legends as in Table 1.

\section{Discussion}

Ionizing irradiation exerts its biological effects by initiating ROS generation through the radiolysis of water. $\mathrm{ROS}$ include $\mathrm{O}_{2}$-derived free radicals including superoxide anion radical $\left(\mathrm{O}_{2}{ }^{-}\right)$and the hydroxyl radical $\left({ }^{-} \mathrm{OH}\right)$, as well 
as non radical derivatives of $\mathrm{O}_{2}$ such as hydrogen peroxide $\left(\mathrm{H}_{2} \mathrm{O}_{2}\right)$. It is a well established fact that ionizing radiation causes damage to DNA, proteins, lipids and carbohydrates in the various organs (Chen et al., 2013). In some organs, damage is expressed early while in others, it may be expressed over a period of time depending upon the cell kinetics and the radiation tolerance of the tissues (Jagetia and Baliga, 2003).

In the present study $\gamma$-irradiation of mice has induced imbalance between oxidant and antioxidant species. Significant elevation in the level of MDA and AOPP levels was accompanied by significant depletion of GSH level in liver, spleen and kidney after 15 days. This may be attributed to the utilization of antioxidants by the enhanced production of ROS (Prasad et al., 2005) or due to the decreased transport activity of the oxidized GSH through membranes with a decrease in the activity of glutathione reductase which is augmented by riboflavin deficiency (Abou-Bedair et al., 2002). Parihar et al. (2006) attributed the increase in tissue MDA to the susceptibility of lipids to free radical attack. Witko-Sarat et al. (1996) suggested that AOPP accumulation that coexisted with decreased GSH and elevated MDA support the occurrence of oxidative stress. An interaction between oxygen and nitrogen species has drawn extensive attention because of the deleterious effects of peroxynitrite on antioxidant systems (Yousefipour et al., 2010). Plasma membrane fluidity and permeability are directly affected by radiation-induced lipid damage (Corre et al., 2010). Free radicals attack biomolecules such as fatty acid component of membrane lipids, proteins and DNA, leading to lipid peroxidation, AOPP, strand breaks and ultimately cell death (Morita et al., 2011). Spleen damage was confirmed by DNA fragmentation and necrosis of DNA of spleenocytes as well as elevation of MDA and AOPP (Salama and Montaser, 2013).

Intra-peritoneal treatment with fractionated $1 / 3 \mathrm{LD}_{50}$ of crude $\mathrm{CCV}$ over 2 weeks, significantly improved oxidative stress in irradiated mice implicating possible antioxidant effect of low doses of $C$. cerastes crude venom. Also Hou et al. (2004) described that the fraction $\mathrm{F}$ and $\mathrm{H}$ isolated from Naja naja atra venom has anti-lipid peroxidation effect, may scavenge active oxygen free radical and increase the activity of SOD. A dose of $1 / 10^{\text {th }} \mathrm{LD}_{50}$ of Naja kaouthia venom and Vipera russelli venom strengthened antioxidant system of Ehrlich ascites carcinoma treated mice (Debnath et al., 2007).

Egypt. J. Rad. Sci. Applic., Vol. 27, No. 1-2 (2014) 
Although trace elements constitute a minor part of living tissues, they are important for vital processes. Some metals, usually present in proteins, enzymes and cellular membranes, are essential for the normal physiological function (Silva, 2009). The present elevation of $\mathrm{Cu}$ and $\mathrm{Zn}$ are in agreement with Cengiz et al. (2003) who noted that deposition of trace elements may have some additional role on the toxicity caused by direct radiation. The increase of $\mathrm{Zn}$ may be due to its accumulation from the damaged lymphoid organs, bone marrow and spermatogonia (Okada, 1970). El-Nimr and Abdel-Rahim (1998) attributed the significant change in the concentrations of essential trace elements in lung, liver, spleen and kidney to the long term disturbances of enzymatic functions and possible retardation of cellular activity by irradiation. The significant decrease in spleen, kidney and liver $\mathrm{Ca}$ in the present study might be attributed to the inhibitory effect of ionizing radiation on Ca ion channels (Nunia et al., 2007). Kotb et al. (1990) attributed the disturbances in calcium metabolism to the insufficient renal function after irradiation. It has previously been observed that calcium homeostasis is essential for the maintenance of cellular mitosis. Induced hypocalcaemia would be expected to depress mitotic activity and may be partially responsible for activity of pathological alterations produced by irradiation. While in the kidney, the iron content was significantly decreased. This was attributed by Hampton and Mayerson (1950) to that the kidney is capable of forming ferritin from iron released from haemoglobin. It is probable that iron present in the kidney is used for excretion and conversion to ferritin.

The venom of $C$. cerastes is a low-complexity proteome composed of 2530 toxins belonging to 6 protein families, mainly targeting the haemostatic system. Cysteine-rich secretory proteins and C-type lectin-like molecules, each accounted for less than $4 \%$ of the total venom toxins (Fahmi et al., 2012).

A protective effect of animal venom was attributed to the cysteine-rich secretory proteins found in animal venoms (CRISP-Vs), which are members of a large family of cysteine-rich secretory proteins (CRISPs) that act on different ion channels as proved in Elapidae, Colubridae and Viperidae families (Ramazanova et al., 2009).

Radiation-induced oxidative stress in the kidney was associated with a significant increase in the level of serum urea and creatinine. Reduction-

Egypt. J. Rad. Sci. Applic., Vol. 27, No. 1-2 (2014) 
oxidation imbalances lead to kidney injury and proteinuria (Nistala et al., 2008). It could be referred to increased ammonia formed by deamination of amino acids in the liver converted to urea (Ganong, 1999). The impaired detoxification function of the liver by irradiation could also contribute in the increase of urea in the blood (Robbins et al., 2001). Serum creatinine elevation might be attributed to the interaction of ionizing radiation with the sites of biosynthesis (El-Kashef and Saada, 1988). Dai et al. (2012) described renal protective effects of Naja naja atra venom (NNAV) treatment, at the dose of $90 \mu \mathrm{g} /(\mathrm{kg} / \mathrm{day})$, in mice with streptozotocin (STZ)-induced diabetes manifested by improved creatinine, blood urea nitrogen, urinary protein excretion, MDA, SOD in serum and kidney tissue in diabetic nephropathy. Egyptian viper Androctonus amoreuxi venom offered radio protective effect to irradiated rat kidneys (Ashry et al., 2012).

In conclusion: $C$. cerastes crude venom at fractionated doses $\left(1 / 3 \mathrm{LD}_{50}\right)$ reduces oxidative stress induced by $\gamma$-rays exposure and prevents trace elements disturbances. The present study provides details about the effect of $C$. cerastes crude venom in mice exposed to whole body $\gamma$-irradiation, suggesting that it could be a natural potential radio protective agent for radiotherapy, though the mechanism is not yet clear.

\section{References}

Abou-Bedair, F. A., Hori, H., Nagasawa, H., Uto, Y., Abu-Zeid, M. and Inayama, S. (2002) Comparison of hypoxic cell radiosensitizers, KIN-804, KIN-844, KIN-806 and TX-1877, on brain and liver metabolizing capacities in mice bearing Ehrlich ascites carcinoma. Biolog. Pharmaceut. Bull., 25, 591.

Al-Sadoon, M. K., Abdel Moneim, A. E., Diab, M. M. and Bauomy, A. A. (2013) Hepatic and renal tissue damages induced by Cerastes cerastes gasperetti crude venom. Life Sci. J., 10, 191.

Ashry, O., Moustafa, M., Baset, A. A., Abu Sinna, G. E. and Farouk, H. (2012) Outcome of venom bradykinin potentiating factor on rennin-angiotensin system in irradiated mice. Int. J. Radiat. Biol., 88, 840.

Beutler, E., Duron, O. and Kelly, B. (1963) Improved method for determination of blood glutathione. J. Lab clin. Med., 61, 882.

Cengiz, M., Gurkaynak, M., Vural, H., Aksoy, N., Cengiz, B., Yildiz, F. and Atahan, I. L. (2003) Tissue trace element change after total body irradiation. Nephron Exp. Nephrol., 94, 12.

Egypt. J. Rad. Sci. Applic., Vol. 27, No. 1-2 (2014) 
Chen, C., Chen, Z., Xu, F., Zhu, C., Fang, F., Shu, S., Li, M. and Ling, C. (2013). Radio-protective effect of catalpol in cultured cells and mice. J. Radiat. Res., 54, 76.

Corre, I., Niaudet, C. and Paris, F. (2010) Plasma membrane signaling induced by ionizing radiation. Mutat. Res., 704, 61.

Dai, G. L., He, J. K., Xie, Y., Han, R., Qin, Z. H. and Zhu, L. J. (2012) Therapeutic potential of Naja naja atra venom in a rat model of diabetic nephropathy. Biomed. Environ. Sci., 25, 630.

Das, T., Bhattacharya, S., Halder, B., Biswas, A., Das Gupta, S., Gomes, A. and Gomes A. (2011) Cytotoxic and antioxidant property of a purified fraction (NN-32) of Indian Naja naja venom on Ehrlich ascites carcinoma in BALB/c mice. Toxicon, 57, 1065.

Debnath, A., Chatterjee, B. and Dasa, M. (2007) Venom of Indian monocellate cobra and Russell's viper show anticancer activity in experimental models. $J$. Ethnopharmacology, 111, 681.

EL-Kashef, H. S. and Saada, H. N. (1988) changes in the level of urea, creatine and creatinine in the liver and serum of irradiation rats. Isotope \& Radiat. Res., 20, 43.

El-Nimr, T. and Abdel-Rahim, S. M. (1998) Effect of gamma radiation on some elements in certain organs of albino rats. Biology Trace element Res., 68, 25.

Edrees, G. M. F., El-Kholy, W. M., El-Habiby, E. M. and El-Sherbiny, S. A. (2008) Protective action of peanut oil in rats exposed to gamma-rays. Belg. J. Zool., 138, 149.

Fahmi, L., Makran, B., Pla, D., Sanz, L., Oukkache, N., Lkhider, M., Harrison R. A., Ghalim, N. and Calvete, J. (2012) Venomics and antivenomics profiles of North African Cerastes cerastes and C. vipera populations reveals a potentially important therapeutic weakness. J. Proteomic., 75, 2442.

Ganong, W. F. (1999) Review of Medical Physiology, 19th Ed. Appelton \& Lang Medical Publications, California, pp. 635-45.

Gomes, A., Bhattacharya, S., Chakraborty, M., Bhattacharjee, P., Mishra, R. and Gomes A. (2010) Anti-arthritic activity of Indian monocellate cobra (Naja kaouthia) venom on adjuvant induced arthritis. Toxicon., 55, 670.

Hampton, J. K. Jr. and Mayerson, H. S. (1950) Hemoglobin iron as a stimulus for the production of ferritin by the kidney. Am. J. Physiol., 160, 1.

Hou, L., He, Q., Zhao, L., Kong, T., Guan, J. and Jiang, Z. (2004) Effect of fractions isolated from Naja naja atra venom on antioxidation in animals. J. Chin. Medicin. Matert., 27, 845.

Jagetia, G. C. and Baliga, M. S. (2003) the evaluation of radioprotective effect of the leaf of Syzygium cumini in the mice exposed to the lethal dose of radiation. Nahrung, 47, 181.

Egypt. J. Rad. Sci. Applic., Vol. 27, No. 1-2 (2014) 
Jozanov-Stankov, O., Demajo, M., Djujic, I. and Mandic, M. (1998) Selenium intake as a modulator of responsiveness to oxidative stress. J. Environ. Pathol. Toxicol. Oncol., 17, 251.

Kingston, H. M. and Jassei, L. B. (1988) Introduction to microwave sample preparation. ACS, Washington. DC, 126-130.

Kotb, M. A., El-Khatib, A. M., Morsey, A. A., Ramadan, M. I. A. and El-Bassiouni, E. A. (1990) Changes in mineral elements tissues of mice following neutron irradiation. Isoto penpaxis, 26, 297.

Morita, M., Ishida, N., Uchiyama, K., Yamaguchi, K., Itoh, Y., Shichiri, M., Yoshida, Y., Hagihara, Y., Naito, Y., Yoshikawa, T. and Niki, E. (2012) Fatty liver induced by free radicals and lipid peroxidation. Free Radic. Res., 46, 758.

Nistala, R., Whaley-Connell, A. and Sowers, J. R. (2008) Redox control of renal function and hypertension. Antioxid. Redox Signal., 10, 2047.

Nunia, V., Sancheti, G. and Goyal, P. K. (2007) Protection of Swiss albino mice against whole-body gamma irradiation by diltiazem. Brit. J. Radiol., 80, 77.

Okada, S. (1970) Radiation induced death. In: Radiation biochemistry' (Altman, K. I., Gerber, G. B. and Okada, S. Eds), Academic Press, New York. Pp. 247-285.

Parihar, V. K., Prabhakar, K. R., Veerapur, V. P., Kumar, M. S., Reddy, Y. R., Joshi, R., Unnikrishnan, M. K. and Rao, C. M. (2006) Effect of sesamol on radiation-induced cytotoxicity in Swiss albino mice. Mutat. Res., 611, 9.

Phelps, T. (2010) Old world vipers, a natural history of the azemiopinae, and viperinae. Edition Chimaira, Frankfurt am Main, hardcover 978-3-89973, pp. 470-476.

Prasad, N., R., Menon, V. P., Vasudev, V. and Pugalendi, K. V. (2005) Radioprotective effect of sesamol on gamma-radiation induced DNA damage, lipid peroxidation and antioxidants levels in cultured human lymphocytes. Toxicology, 209, 225.

Ramazanova, A. S., Starkov, V. G., Osipovm, A. V., Ziganshin, R. H., Filkin, S. Y., Tsetlin, V. I. and Utkin, Y. N. (2009) Cysteine-rich venom proteins from the snakes of Viperinae subfamily-Molecular cloning and phylogenetic relationship. Toxicon, 53, 162.

Robbins, M. E., O'Malley, Y., Zhao, W., Davis, C., Bonsib, S. (2001) The role of the tubulointerstitium in radiation-induced renal fibrosis. Radiat. Res., 155, 481.

Salama, S. F. and Montaser, S. A. (2013) Possible modulating impact of glutathione disulfide mimetic on physiological changes in irradiated rats. Hum. Experi. Toxicol., under press.

Shirazi, A., Mihandoost, E., Mohseni, M., Ghazi-Khansari, M., Rabie Mahdavi, S. (2013) Radio-protective effects of melatonin against irradiation-induced oxidative damage in rat peripheral blood. Physica. Medica., 29, 65.

Egypt. J. Rad. Sci. Applic., Vol. 27, No. 1-2 (2014) 
Silva, M. P., Tomal, A., Perez, C. A., Ribeiro-Silva, A. and Poletti, M. E. (2009) Determination of $\mathrm{Ca}, \mathrm{Fe}, \mathrm{Cu}$ and $\mathrm{Zn}$ and their correlations in breast cancer and normal adjacent tissues. X-Ray Spectrom, 38, 103.

Spierto, F. W., Macneil, M. L. and Burtis, C. A. (1979) The effect of temperature and wavelength on the measurement of creatinine with the jaffe' s procedure. Clin. Biochem., 12, 18 .

Suntravat, M., Nuchprayoon, I. and Perez, J. C. (2010) Comparative study of anticoagulant and procoagulant properties of 28 snake venoms from families Elapidae, Viperidae, and purified Russell's viper venom-factor X activator (RVV-X). Toxicon, 56, 544.

Witko-Sarsat, V., Friedlander, M., Capeillere-Blandin, C., Nguyen-Khoa, T., Nguyen, A. T., Zingraff, J., Jungers, P. and Deschamps-Latscha, B. (1996) Advanced oxidation protein products as a novel marker of oxidative stress in uraemia. Kidney Int J., 49, 1304.

Witko-Sarsat, V., Friedlander, M., Nguyen Khoa, T., Capeillère-Blandin, C., Nguyen, A. T., Canteloup, S., Dayer, J. M., Jungers, P., Drüeke, T. and DescampsLatscha, B. (1998) Advanced oxidation protein products as novel mediators of inflammation and monocyte activation in chronic renal failure. J. Immuno., 161, 2524.

Yoshioka, T., Kawada, K., Shimada, T. and Mori, M. (1979) Lipid peroxidation in maternal cord blood and protective mechanism against activated oxygen toxicity in blood. Am. J. Obstet Gynecol., 135, 372.

Young, D. S (2001) Effects of disease on clinical laboratory tests. $4^{\text {th }}$ Edition, Vol. 1 and 2. D.S. Young and R.B. Friedman, eds. Washington, DC: AACC Press.

Yousefipour, Z., Oyekan, A. and Newaz, M. (2010) Interaction of oxidative stress, nitric oxide and peroxisome proliferator activated receptor gamma in acute renal failure. Pharmacol. Ther., 125, 436.

(Received: 06/04/2014;

accepted: 01/06/2014)

Egypt. J. Rad. Sci. Applic., Vol. 27, No. 1-2 (2014) 


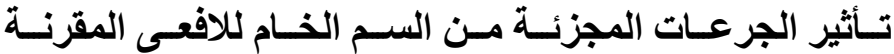

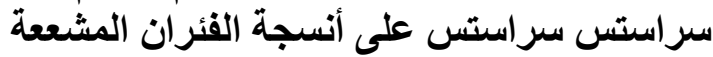 اميمة محمد عشري و صفوت فريد سلامة و هشام فاروق حسن

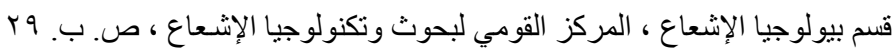

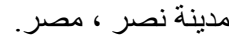

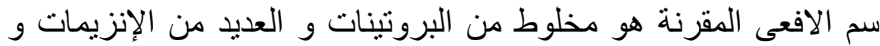

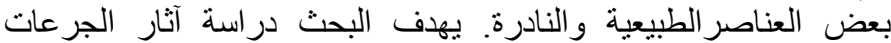

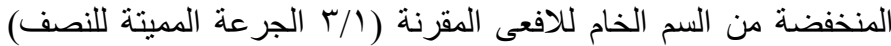

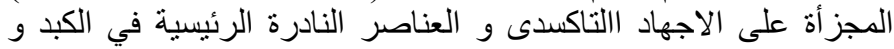

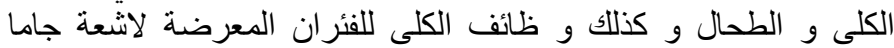

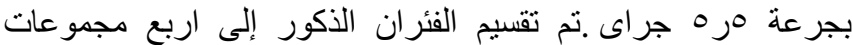

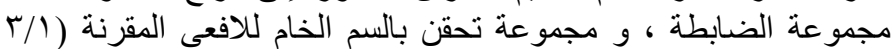

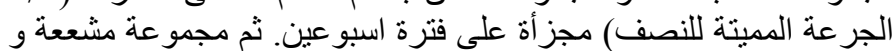

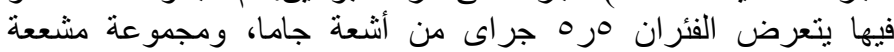

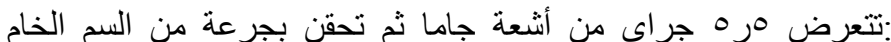

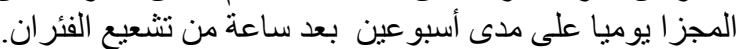

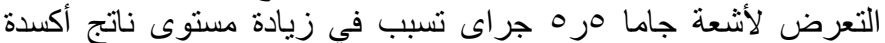

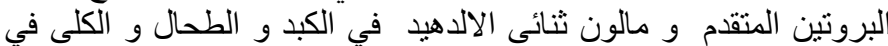

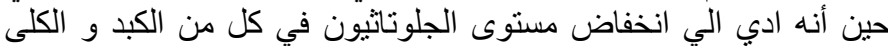

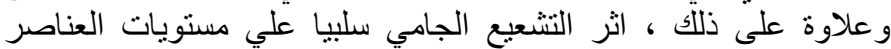

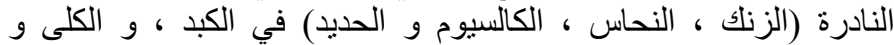

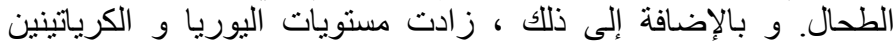

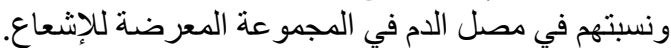

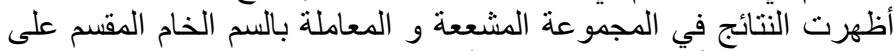

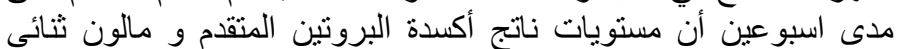

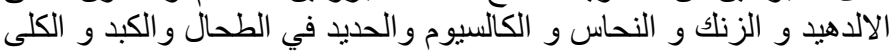

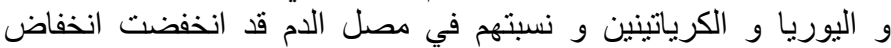
معنوى بينما ارتفع كل من الجلوتاثيون في الكبديد و الجلوناثيونيون في الكلى بالمقارنة مع مجموعة المشععة الضابطة.

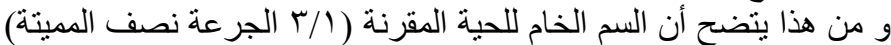

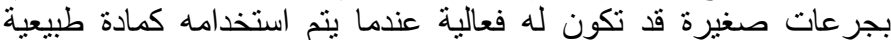
للتخفيف من حدة الإصابات البيوكيميائية التي يسبيها الاشعاع في الأنسجة. 